\title{
The Use of Serum Survivin and AFP-L3 and their Combination in Improving Hepatocellular Carcinoma Diagnosis Especially in Patients with Low Serum AFP
}

\author{
MAHMOUD MOAWAD, Ph.D.* and ANWAR MOHAMED, M.D.** \\ The Departments of Surgical Pathology, National Cancer Institute, Cairo University* and Hepatology, National Liver Institute, \\ Menoufia University**, Menoufia, Egypt
}

\begin{abstract}
Background: Hepatocellular carcinoma (HCC) is responsible for about $4.7 \%$ of chronic liver disease in Egypt. Survivin is an essential element in apoptosis inhibition. Survivin is present in fetal and malignant adult tissue and is absent in non malignant tissues. A diagnostic and prognostic HCC marker is the alpha-fetoprotein (AFP) binding to Lens culinaris agglutinin (AFP-L3\%) percentage. There is a need for HCC marker that is better than AFP especially in those low AFP.
\end{abstract}

Aim of Study: To detect the role of determination of serum Survivin gene, AFP-L3\% and their combination in HCC diagnosis.

Subjects and Methods: Fifty HCC patients and 20 healthy control persons were subjected for measurement of serum AFP, survivin gene and AFP-L3\%. Reverse transcriptionpolymerase chain reaction (RT-PCR) was used for detection of serum survivin gene. AFP-L3\% was measured by a liquidphase binding assay on the Wako LiBASys clinical auto analyzer.

Results: Serum Survivin gene was positive in $27(54 \%)$ $\mathrm{HCC}$ cases and negative in $23(46 \%)$ cases. AFP-L3\% was detected in $36(72 \%)$ HCC cases. The combined use of serum servivin gene and AFP-L3\% were positive in $43(86 \%)$ of HCC cases. In $22 \mathrm{HCC}$ cases with serum AFP below 200 $\mathrm{ng} / \mathrm{ml}$ serum servivin gene was detected in $9(40.9 \%)$ cases but AFP-L3\% was positive in $13(59.9 \%)$ cases and the combined use of positive serum servivin and AFP-L3 were present in 18 cases $(81.18 \%)$.

Conclusions: The combined use of serum survivin gene and AFP-L3\% could have a valuable diagnostic role in HCC especially in those with low AFP.

Key Words: HCC - Survivin - AFP - AFP-L3 - Tumor markers.

\section{Introduction}

HEPATOCELLULAR carcinoma (HCC) is the third cause of cancer mortality worldwide. The

Correspondence to: Dr. Mahmoud Moawad, The Department of Surgical Pathology, National Cancer Institute, Cairo University Egypt
HCC incidence in Egypt had increased. HCC risk factors such as hepatitis C, B infection are present in Egypt Madden et al., [1]. Tumor markers are used for screening and early diagnosis of malignancies. Although, early HCC detection is still difficult because of absence of a suitable HCC marker that shows high sensitivity and specificity [2]. Survivin is essential in apoptosis inhibition. Survivin is expressed in most human neoplasms and is present in fetal and malignant adult tissue [3]. The inhibition of caspases are the main functions of survivin. This promotes mitosis and increases survival of cancer cells. It is responsible for resistance to chemotherapeutic drugs in HCC. The degree of survivin gene expression correlates with tumor aggressiveness and bad clinical outcome [4]. The improvement of AFP sensitivity can be increased by measuring the isoforms of AFP [5] The percentage of AFP-L3 over the total AFP levels is used as a specific index for HCC. AFP-L3 could be used as a screening and diagnostic markers for HCC in high risk patients [6]. There is a need for an ideal tumor marker for HCC instead of depending on the AFP particularly in those with low serum level of AFP. The present study was designed to detect the value of measurement of serum Survivin gene and AFP-L3\% and their combination in improving $\mathrm{HCC}$ diagnosis.

\section{Patients and Methods}

This study included $50 \mathrm{HCC}$ patients and 20 healthy volunteers as a control. The diagnosis of $\mathrm{HCC}$ was done according to the American Association for the Study of Liver Diseases (AASLD) practice guidelines 2011 (one imaging technique (CT or MRI) showing the HCC radiological criteria (contrast uptake in the arterial phase and washout in the venous/late phase) of hepatic focal lesion 
more than one $\mathrm{cm}$ in a cirrhotic patient [7]. Those with past history of other malignancies and patients on chemotherapy whatever the etiology were excluded from this study. Samples of peripheral blood collected from HCC patients that had attended to National Liver Institute outpatient clinic-Menoufia University and another 20 samples from apparently healthy volunteer subjects with no viral hepatitis infection and HCC.

\section{All patients and control groups were submitted to: Laboratory investigations:}

Under complete aseptic technique; $10 \mathrm{ml}$ of blood were obtained from each participant. These were samples used for estimations of CBC, AST, ALT, Bilirubin, albumin, creatinine and INR. Serological markers for viral hepatitis: (HBsAg, anti$\mathrm{HCV} \mathrm{Ab}$ ) using ELISA supplied by Sorine-Italy. Serum Alpha fetoprotein was determined by kits from Bayer (Germany) using ACS: 180 (automated chemiluminenscene system). SerumAFP-L3\% was measured by a liquid-phase binding assay on the Wako LiBASys clinical auto analyzer. Those with AFP-L3\% above $10 \%$ were considered positive (having HCC) and those below 10\% were considered negative (No HCC).

\section{Molecular studies for survivin gene:}

Survivin gene was measured by Reverse transcription polymerase chain reaction (RTPCR) and the test results are either positive or negative according to Bo et al., [8] . One $\mathrm{mL}$ of Peripheral blood samples were collected in EDTA, then nucleated cells were isolated for RNA extraction and PCR analysis by using QIA amp RNA extraction kit. Primers for Survivin and B actin amplification (Using RT-PCR kits: Qiagen (Catalog number: 12110007. Primer-1 (sense strand primer) for Survivin The survivin mRNA Genbank accession number is NM001168. It had the following sequence: 5'-ACCAGGTGAGAAGTGAGGGA-3'. primer-2 (Anti-sense strand primer) for Survivin 5'-AACAGTAGAGGAGCCAGGGA-3'. For B actin amplification, the $B$ actin mRNA Genbank accession number is NM-001101 Primer-1 (sense strand primer). It had the following sequence: 5'TGACGGGGTCACCCACACTG3'. Primer-2 (Anti-sense strand primer): 5'CTAGAAGCA TTTGCGGTGGA 3'. All reaction tubes incubated at $55^{\circ} \mathrm{C}$ for 30 minutes for c-DNA synthesis at thermal cycler then, incubated at $95^{\circ} \mathrm{C}$ for 15 minutes to inactivate the reverse transcriptase and to completely denaturate the template. For PCR amplification of Survivin, denaturation: $94^{\circ} \mathrm{C}$ for $60 \mathrm{sec}$, annealing: $59^{\circ} \mathrm{C}$ for $60 \mathrm{sec}$, polymerization: $72^{\circ} \mathrm{C}$ for $60 \mathrm{sec}$, final extension $72^{\circ} \mathrm{C}$ for $10 \mathrm{~min}$, this was repeated for a total of 32 cycles. For PCR amplification of B- actin, denaturation: $94^{\circ} \mathrm{C}$ for $60 \mathrm{sec}$. annealing: $55^{\circ} \mathrm{C}$ for $60 \mathrm{sec}$. polymerization: $72^{\circ} \mathrm{C}$ for $1 \mathrm{~min}$, followed by a final extension cycle at $72^{\circ} \mathrm{C}$ for $10 \mathrm{~min}$. Amplified material was stored at $-20^{\circ} \mathrm{C}$ until gel electrophoresis was performed using their different molecular weight (308bp for Survivin and 600bp for B-actin).

\section{Radiological investigations:}

Abdominal ultrasound was done and those with hepatic focal lesion were subjected to triphasic spiral CT or MRI and patients with HCC criteria mentioned before were selected and included in this study.

\section{Statistical analysis:}

Statistical analysis was performed using SPSS version 17.0 software. Results are expressed as mean \pm standard deviation (SD), and the pairedsample $t$-test to analyze for each group. The results were considered statistically significant if the $p<0.05$, and highly significant if less than 0.001.

\section{Results}

Fifty HCC patients and 20 control persons were included in this study. Demographic data and clinicopathological features of the studied groups were shown in Tables $(1,2)$. Fifty HCC patients, had ages ranged between 39-65 years with mean age $50 \pm 9$ years. Twenty healthy controls, with ages ranged between 34-63 years with mean age $39 \pm 10$ years were included as regard to gender distribution between the two groups, in HCC group 35 (70\%) of cases were males and $15(30 \%)$ were females, and in control $13(65 \%)$ were males. In case of serum AFP, there was a statistically significant difference in the different groups with $(p<0.001)$, where the lowest serum AFP level was detected in the control group (2.59 \pm 1.63$)$ and AFP in HCC group was (3625 \pm 1219$)$ Table (2). Serum Survivin gene detected by RT PCR in $27(54 \%)$ HCC cases and negative in $23(46 \%)$ cases. Survivin gene was not detected in any case of the control group Table (3), Fig (1). There was a statistically significant between the different groups in serum survivin gene and AFP-L3. The level of AFP-L3\% above $10 \%$ was detected in $36(72 \%)$ of HCC cases. The positivity of serum servivin gene and AFP-L3\% were present in $43(86 \%)$ HCC cases Table (3). In our study, there were 28 (56\%) HCC patients with serum AFP > 200ng/ml and 22 (44\%) HCC patients with AFP $\leq 200 \mathrm{ng} / \mathrm{ml}$. In HCC cases with serum AFP above $200 \mathrm{ng} / \mathrm{ml}$, serum Servivin gene was detected in $18(64.28 \%)$ cases but AFP-L3\% above $10 \%$ was positive in $24(85.71 \%)$ cases and the 
combined positivity of serum servivin gene and AFP-L3 above $10 \%$ were positive in 25 cases ( 89 . $28 \%$ ) Table (4). In HCC cases with serum AFP below $200 \mathrm{ng} / \mathrm{ml}$ serum servivin gene was detected

Table (1): Demographic data of the studied groups.

\begin{tabular}{lll}
\hline & $\begin{array}{c}\text { Control } \\
\text { group }\end{array}$ & $\begin{array}{l}\text { HCC } \\
\text { group }\end{array}$ \\
\hline Age: & & \\
Mean \pm SD & $34-63$ & $50 \pm 9$ \\
Range & $39 \pm 10$ & $39-65$ \\
Gender: & & \\
Male & $13(65 \%)$ & $35(70 \%)$ \\
Female & $7(35 \%)$ & $15(30 \%)$ \\
DM & $0(0 \%)$ & $9(18 \%)$ \\
Hypertension & $0(0 \%)$ & $5(10 \%)$ \\
Smoking & $0(0 \%)$ & $10(20 \%)$ \\
\hline
\end{tabular}

Table (3): Correlation between serum Survivin gene expression by RT-PCR and AFP-L3\% in the studied groups.

\begin{tabular}{|c|c|c|c|}
\hline Parameters & $\begin{array}{l}\text { Controls } \\
(\mathrm{n}=20)\end{array}$ & $\begin{array}{c}\text { HCC Cases } \\
\quad(n=50)\end{array}$ & $p$-value \\
\hline \multicolumn{4}{|l|}{ Survivin: } \\
\hline$-\mathrm{ve}$ & $20(100 \%)$ & $23(46 \%)$ & $<0.001 * * *$ \\
\hline$+v e$ & $0(0 \%)$ & $27(54 \%)$ & \\
\hline \multicolumn{4}{|l|}{$A F P-L 3 \%:$} \\
\hline$\leq 10 \%(-\mathrm{ve})$ & $0(0 \%)$ & $14(28 \%)$ & $<0.001 * * *$ \\
\hline$>10 \%(+v e)$ & $(0 \%)$ & $36(72 \%)$ & \\
\hline \multicolumn{4}{|c|}{$\begin{array}{l}\text { Combined Survivin } \\
\text { and AFP-L3\%: }\end{array}$} \\
\hline$-\mathrm{ve}$ & $20(100 \%)$ & $7(14 \%)$ & $<0.001 * * *$ \\
\hline$+\mathrm{ve}$ & $0(0.0 \%)$ & $43(86 \%)$ & \\
\hline
\end{tabular}

The combination was used in parallel .

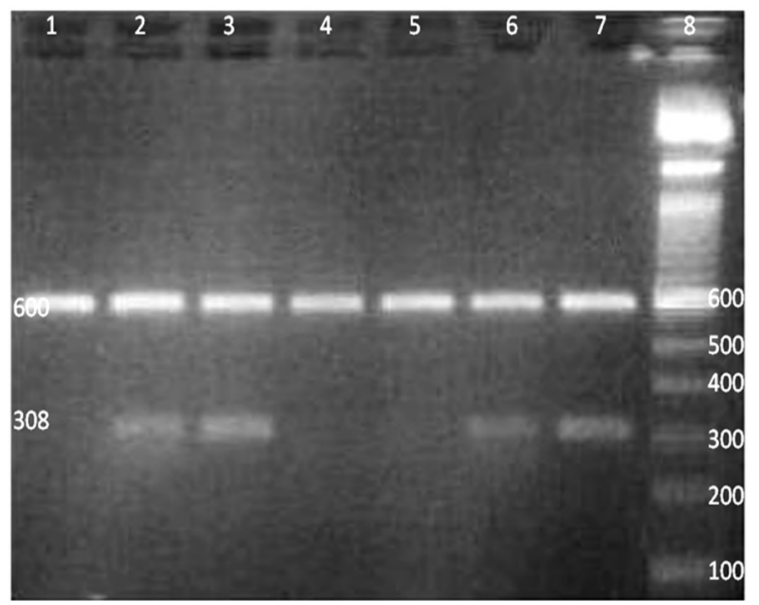

in $9(40.9 \%)$ cases but AFP-L3\% was positive in $12(54.54 \%)$ cases and the combined positivity of serum Servivin gene and AFP-L3 above $10 \%$ were positive in 18 cases $(81.18 \%)$ Table (4).

Table (2): Control group versus HCC group in relation to different studied variables.

\begin{tabular}{lll}
\hline $\begin{array}{l}\text { Studied } \\
\text { variables }\end{array}$ & $\begin{array}{c}\text { Control group } \\
(\mathrm{N}=20) \\
\text { Mean } \pm \text { SD }\end{array}$ & $\begin{array}{l}\text { HCC group } \\
(\mathrm{N}=50) \\
\text { Mean } \pm \text { SD }\end{array}$ \\
\hline Hb \% & $13.6 \pm 1.04$ & $11.1 \pm 1.75$ \\
TLC & $7756.7 \pm 1029.13$ & $5937.2 \pm 3754.5$ \\
Platelets & $267133.3 \pm 53772$ & $148666.7 \pm 917114$ \\
AST $(\mathrm{IU} / \mathrm{ml})$ & $18.4 \pm 4.07$ & $98.06 \pm 52.9$ \\
ALT $(\mathrm{IU} / \mathrm{ml})$ & $24.4 \pm 5.96$ & $58.7 \pm 37.2$ \\
T.Bil $(\mathrm{gm} / \mathrm{dl})$ & $0.68 \pm 0.13$ & $4.03 \pm 6.07$ \\
Alb $(\mathrm{g} / \mathrm{dl})$ & $4.28 \pm 0.37$ & $2.81 \pm 0.82$ \\
Prothrombin & $92.1 \pm 6.42$ & $63.2 \pm 18.6$ \\
$\quad$ concentration & & \\
HCV Ab positive & $0 \%$ & $48(96 \%)$ \\
HBsAg positive & $0 \%$ & $2(4 \%)$ \\
Portal vein diameter & $10.07 \pm 18$ & $14.8 \pm 1.7$ \\
AFP $(\mathrm{ng} / \mathrm{ml})$ & $2.59 \pm 1.63$ & $3625 \pm 1219$ \\
\hline
\end{tabular}

Table (4): Survivn gene and AFP-L3\% in relation to AFP level (>200 and $\leq 200 \mathrm{ng} / \mathrm{ml}$ ) in HCC group.

\begin{tabular}{|c|c|c|c|c|c|}
\hline \multirow{3}{*}{ Parameters } & \multicolumn{4}{|c|}{ AFP } & \multirow{3}{*}{$p$-value } \\
\hline & \multicolumn{2}{|c|}{$\begin{array}{c}>200 \mathrm{ng} / \mathrm{ml} \\
(\mathrm{N}=28) \\
(56 \%)\end{array}$} & \multicolumn{2}{|c|}{$\begin{array}{c}\leq 200 \mathrm{ng} / \mathrm{ml} \\
(\mathrm{N}=22) \\
(46 \%)\end{array}$} & \\
\hline & No. & $\%$ & No. & $\%$ & \\
\hline \multicolumn{6}{|l|}{ Survivin gene: } \\
\hline- ve & 10 & 35.71 & 13 & 59.9 & $<0.09$ \\
\hline +ve & 18 & 64.3 & 9 & 40.90 & \\
\hline \multicolumn{6}{|l|}{ AFP-L3\%: } \\
\hline$\leq 10 \%(-\mathrm{ve})$ & 4 & 14.28 & 10 & 45.45 & $<0.01 * *$ \\
\hline$>10 \%(+\mathrm{ve})$ & 24 & 85.71 & 12 & 54.54 & \\
\hline \multicolumn{6}{|c|}{$\begin{array}{l}\text { Combined Survivin } \\
\text { and AFP-L3\%: }\end{array}$} \\
\hline- ve & 3 & 10.71 & 4 & 18.18 & $<0.68$ \\
\hline +ve & 25 & 89.28 & 18 & 81.18 & \\
\hline
\end{tabular}

FE=Fisher's Exact test. The combination was used in parallel.

Fig. (1): Detection of surviven gene expression, electrophoresis separation of survivin (308 bp) and single copy gene B-actin $(600 \mathrm{bp})$ RT-PCR amplified fragments on $2 \%$ agarose gel. Lane 1 control case for surviven expression, Lane 2,3,6 and $7 \mathrm{HCC}$ tumors positive for surviven expression, Lane 4 and 5 HCC tumors negative for surviven expression. Lane 8: 100 bp molecular weight marker. 


\section{Discussion}

Cancer is the second leading cause of mortality after cardiovascular diseases Madden et al., [1] Prognosis of $\mathrm{HCC}$ is worse; thus early diagnosis of HCC is precious especially in patients with chronic liver disease and cirrhosis Yang and Poon, [9]. Early detection of hepatocellular carcinoma is still difficult because markers of HCC had no acceptable sensitivity and specificity Elshemey et al., [10]. In our study, the prevalence of HCC in men is more than women with a male to female ratio of about 2:1. This finding is in accordance with Sherman, [11]. Exposures to risk factors are more common in males [12]. In the present study the mean age in HCC group was $50 \pm 9$ years. This matches with the known evidence that the incidence of HCC increases over the age of 45 and continues to increase till the seventies [11]. Survivin is one of the eight proteins involved in inhibition of apoptosis. It is detected in neoplastic adult tissues. Survivin is essential in tumour formation / progression, especially angiogenesis [13]. The Lens culinaris agglutinin-reactive fraction of alpha-fetoprotein (AFP-L3) is considered as a sensitive and a specific tumor marker for HCC. Moreover, it can be used an indicator of the prognosis of patients with HCC [14]. HCC is almost present in cirrhotic HCC patients with AFP-L3 above 10\% even when imaging techniques cannot identify tumors [15] The aim of this study is to detect the diagnostic value of combined measurement of serum Survivin gene and AFP-L3\% in HCC diagnosis especially in patients with low serum AFP. In our study the mean serum AFP levels in control and HCC groups were $2.59 \pm 1.63$ and $3651 \pm 1219 \mathrm{ng} / \mathrm{ml}$ respectively with a statistically significant difference between the studied groups. This is in agreement with Leerapun et al., [14]. Serum AFP level above $200 \mathrm{ng} / \mathrm{ml}$ was considered diagnostic for HCC in cirrhotic patients with hypervacular hepatic focal lesion on imaging according AASLD guidelines in 2005 Bruix and Sherman, [16]. In our series, AFP more than $200 \mathrm{ng} / \mathrm{ml}$ was detected in $28(56 \%)$ of HCC. AFP below $200 \mathrm{ng} / \mathrm{ml}$ was present in 22 (44\%) HCC cases. AFP could be normal in about $40 \%$ of HCC patients Bruix and Sherman, [16]. In the present study, serum survivin is positive in $27(54 \%)$ of HCC specimens. The survivin gene was expressed in a most of HCC tissues but not in liver cirrhosis tissues which indicates survivin gene may have a role in development and diagnosis of HCC. Chiu et al., [17] showed that Survivin is one of the pathogenic markers involved in HCC recurrence after living donor liver transplantation as Oncogenes is present in new graft and in the peripheral blood. Furthermore, Hung et al., [18] found that the extent of HCC malignancy is strongly associated with survivin expression. They suggest that analyzing survivin expression in HCC tumors before treatment can identify HCC patients who would benefit from molecular targeting- survivin agents [19]. In the present study, AFP-L3\%>10\% increased significantly in HCC group compared to control and considered as diagnostic for HCC. The level of AFP-L3 above 10\% was detected in $38(76 \%)$ of HCC cases. AFP-L3\% above $10 \%$ in HCC patients with AFP values less than $200 \mathrm{ng} / \mathrm{ml}$ was present in 12 cases and this allows the confident diagnosis of an additional $24 \%$ of HCC cases. This is in agreement with Leerapun et al., as this allowed the additional diagnosis of $10 \%$ of HCC cases in their study using AFP-L3 more than 35\%. In an attempt to enhance the $\mathrm{HCC}$ detection rate, we investigated the use of combined markers. The combined use of Serum servivin gene and AFPL3\% were present in 43 cases (86\%) of HCC cases. In $22 \mathrm{HCC}$ cases with serum AFP below $200 \mathrm{ng} / \mathrm{ml}$, serum Servivin gene was detected in $9(40.9 \%)$ cases but AFP-L3\% more than $10 \%$ was positive in $12(54.54 \%)$ cases. So in our study, the determination of combined serum AFP-L3\% and survivin gene improved HCC diagnostic value. Studies suggested the combined use of more than one tumor marker for HCC allowed the improvement in HCC diagnosis. For example, the use of combining AFP, AFP-L3, and PIVKA-II improve the diagnostic accuracy of HCC in cirrhotic patients compared with using each marker alone [20]. Hann et al., [21] reported that the combined use of AFP, AFP-L3\% and DCP in HCC diagnosis is associated with increased diagnostic value mainly in individuals with negative imaging results. Finally it could be concluded that the combined use of positive serum AFP-L3\% and survivin gene were detected in $86 \%$ of $\mathrm{HCC}$ cases However in those with serum AFP below 200ng/ml, they were present in $81.1 \%$ of HCC cases. Thus the combined use of serum Survivin gene and AFP-L3\% as tumor marker for $\mathrm{HCC}$ is better than the use of one marker alone particularly in those with low serum AFP and in conclusion imaging techniques as CT, MRI, further research studies are required to detect the impact of different treatment modalities for HCC on serum survivrin gene and AFP-L3\%.

\section{References}

1- MADDEN C.R., FINEGOLD M.J. and SLAGLE B.L. (2002). Altered DNA mutation spectrum in aflatoxin b 1 -treated transgenic mice that express the hepatitis B virus X Protein. J. Virol., 76: 11770-4, 2002.

2- BENEDUCE L., CASTALDI F., MARINO M., QUATRA S., RUVOLETTO M., BENVEGNU L., CALABRESE F., GATTA A., PONTISSO P. and FASSINA G.: Squa- 
mous cell carcinoma antigen immunoglobulin $\mathrm{M}$ complexes as novel biomarkers for hepatocellular carcinoma. Cancer, 103: 2558-65, 2005.

3- YE C.P, QIU C.Z. and HUANG Z.X.: Relationship between survivin expression and recurrence, and prognosis in hepatocellular carcinoma. World J. Gastroenterol., 13: 6264-8, 2007.

4- ALMHANNA K., KIM R. and KALMADI S.: Treatment approaches for hepatocellular Carcinoma. Oncology, 1: 11.9, 2007.

5- KUMADA T., TOYODA H. and KIRIYAMA S.: Predictive value of tumor markers for hepatocarcinogenesis in patients with hepatitis C virus. J. Gastroenterol., 46: 53644, 2011.

6- ZHANG Z., ZHANG Y. and WANG Y.: Alpha-fetoproteinL3 and Golgi protein 73 may serve as candidate biomarkers for diagnosing alphafetoprotein-negative hepatocellular carcinoma. Onco Targets Ther., 9: 123, 2016.

7- BRUIX J. and SHERMAN.: Management of Hepatocellular Carcinoma: An. Update. Hepatology, 53: 1020-35, 2011.

8- BO T., XINGSI L., FANG T., JING Z., SIEN Z., SHENGJIAN J., LIHOU Z., YASUSEI K. and GUANGYING Q.I.: Expression of USP22 and Survivin is an indicator of malignant behavior in hepatocellular carcinoma. International Jornal of Oncology, 7: 2208-2216, 2015.

9- YANG Z.F. and POON R.T.: Vascular changes in hepatocellular carcinoma. Anatom Rec., 291: 721-34, 2008.

10-ELSHEMEY W.M., DESSOUKY O.S. and MOHAMMED M.S.: Characterization of cirrhosis and hepatocellular carcinoma using low-angle X-ray scattering signatures of serum. Phys. Med. Biol., 48: 239-46, 2003.

11-SHERMAN M.: Hepatocellular Carcinoma: Epidemiology, risk factors, and screening. Semin. Liver. Dis., 25 (2): $143-54,2005$

12- LOK A.S., SEEFF L.B., MORGAN T.R., di BISCEGLIE A.M., STERLING R.K., CURTO T.M., EVERSON G.T., LINDSAY K.L., LEE W.M., BONKOVSKY H.L., DIENSTAG J.L., GHANY M.G., MORISHIMA C. and GOODMAN Z.D.: HALT-C Trial Group Incidence of hepatocellular carcinoma and associated risk factors in hepatitis C-related advanced liver disease. Gastroenterology, 136 (1): 138-48, 2009.
13- JAISWAL K.P., GOEL A. and MITTAL R.D.: Survivin A molecular biomarker in cancer. Indian. J. Med. Res., 141, April., pp, 389-397, 2015.

14-LEERAPUN A., SURAVARAPU S.V., BIDA J.P, CLARK R.J., SANDERS E.L., METTLER T.A., STADHEIM L.M., ADERCA I., MOSER C.D., NAGORNEY D.M., LARUSSO N.F., de GROEN P.C., MENON K.V., LAZARIDIS K.N., GORES G.J., CHARLTON M.R., ROBERTS R.O., THERNEAU T.M., KATZMANN J.A. and ROBERTS L.R.: The utility of Lens culinaris agglutininreactive alpha-fetoprotein in the diagnosis of hepatocellular carcinoma: Evaluation in a United States referral population. Clin. Gastroenterol. Hepatol., 5 (3): 394-402, 2007.

15- JOHNSON P.J., LEUNG N., CHENG P., WELBY C. LEUNG W.T., LAU W.Y., YU S. and HO S.: Hepatomaspecific. Alpha-fetoprotein may permit preclinical diagnosis of malignantchange in patients with chronic liver disease. Br. J. Cancer, 75: 236-40, 1997.

16- BRUIX J. and SHERMAN M.: AASLD practice guidelines Management of Hepatocellular Carcinoma. Hepatology, 42 (5): 1208-36, 2005

17- CHIU K.W., NAKANO T., CHEN K.D., HSU L.W., LAI C.Y., HUANG C.Y., CHENG Y.F., GOTO S. and CHEN C.L.: Repeated-measures implication of hepatocellular carcinoma biomarkers in living donor liver transplantation. PLoS, 1510 (5), 2015.

18- HUNG C.S., LIU H.H., HUANG M.T., CHENG C.W., KUO L.J., HO Y.S. and WU C.H.: Knockdown survivin expression reduces the efficacy of curcumin treatment in hepatocellular carcinoma cells. Ann. Surg. Oncol., 19 (11): 3547-55, 2012.

19- OR Y.Y.1., CHOW A.K.1., NG L.1., FAN S.T.1., YAU T.C.1., POON R.T.1. and PANG R.W.1.: Survivin depletion inhibits tumor growth and enhances chemosensitivity in hepatocellularcarcinoma. Mol. Med. Rep., 10 (4): 202530, 2014.

20- LIM T.S., KIM do Y. and HAN K.H.: Combined use of AFP, PIVKA-II, and AFP-L3 as tumor markers enhances diagnostic accuracy for hepatocellular carcinoma in cirrhotic patients. Scand. J. Gastroenterol., 51: 344-53, 2016.

21- HANN H.W., LI D., YAMADA H., SATOMURA S. and COBEN R.: Usefulness of Highly Sensitive AFP-L3 and DCP in Surveillance for Hepatocellular Carcinoma in Patients with a Normal Alpha-Fetoprotein. J. Med. Microb. Diagn., 3: 1-6, 2014. 


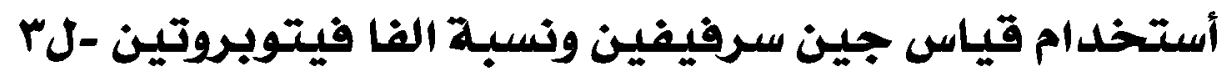

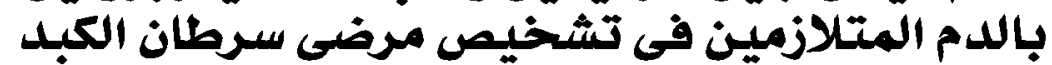

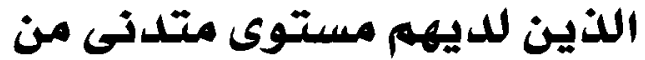

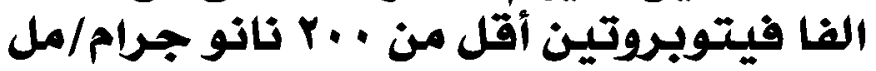

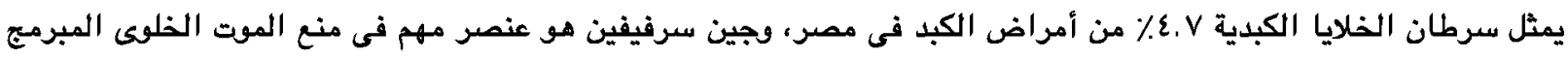

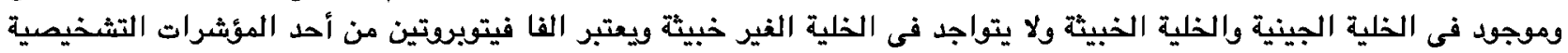

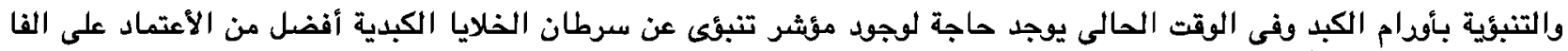

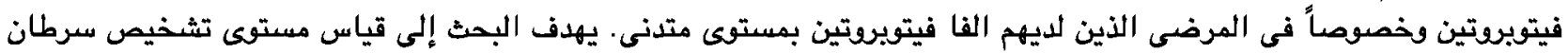

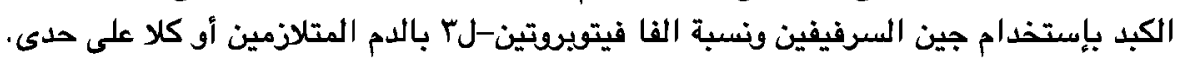

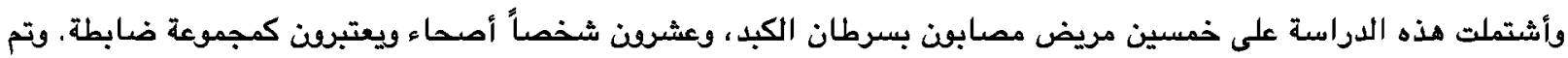

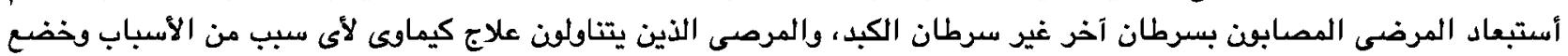

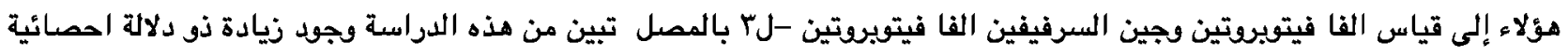

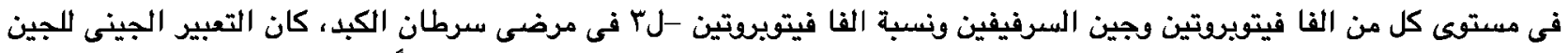

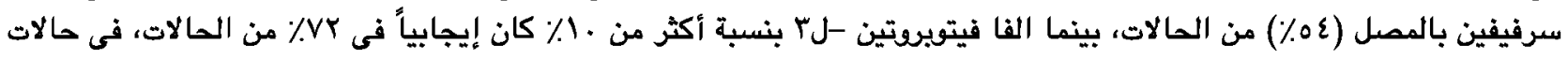

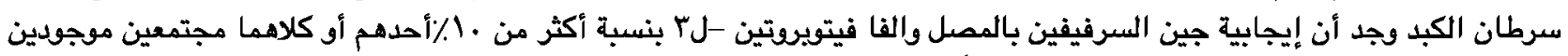

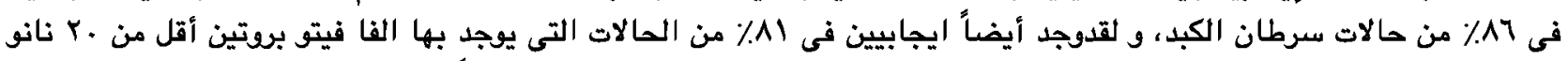

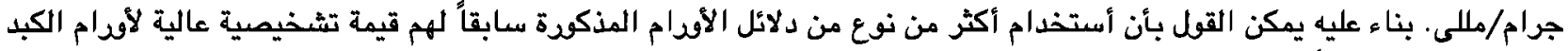

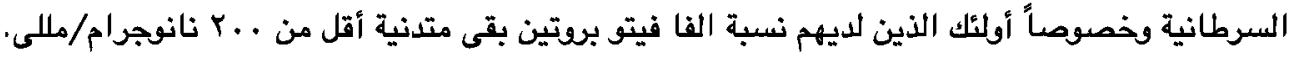

